\title{
Bottleneck and Prospect of Castor Industry
}

\author{
Xuegui Yin*, Jiannong Lu and Yuzhen Shi \\ College of agricultural sciences, Guangdong ocean university, China
}

Submission: July 19, 2017; Published: August 04, 2017

*Corresponding author: Xuegui Yin, College of agricultural sciences, Guangdong ocean university, Zhanjiang, China, 524088, Tel: 86-13828240166; Email: yinxuegui@126.com

\section{Introduction}

Castor (Ricinus communis $L)$ is a diploid $(2 \mathrm{n}=2 \mathrm{x}=20)$ species belonging to Euphorbiaceae, which can be found in tropical or subtropical regions and now is planted all over the world [1]. It is a important industrial crop because its seeds contain an oil with unique chemical and physical properties for industrial uses. As the only commercial source of a hydroxylated fatty acid, castor oil is very important to the global special chemical industry [2], which is widely used in engineering industry, medicine, textile, material, cosmetics and many other fields covering from lower molecular weight aviation fuels, fuel additives, biopolymers, nano composites, biodiesel, phyto remediation to lubricant [310]. Castor oil can substitute for petroleum as energy, material and chemical resources, while many products and chemical derivatives of castor oil have had no alternative materials yet. Castor is cultivated on commercial scale in an area of 1.5 million ha in 30 countries. India, China, Brazil, Russia, Thailand, Ethiopia and Philippines are the major castor growing countries in the world [11]. The imports and exports of castor oil from prominent countries were estimated to be near 0.3 million tons respectively and the demand for castor oil in the world is rising at 3 5\% per annum [12]. However, Castor industry has been suffering a lot from the shortage of raw material because of its low yield per unit area. Breeding high yielding hybrid varietys using pistillate lines has been the main direction of castor breeding but progressed slowly due to the lack of profound understanding of the genetic mechanism in pistillate character. Apart from the costly and laborious work in breeding pistillate lines, castor heterosis application has been plagued for a long time by the contradiction between the un homogeneity and the low restorability of hybrid due to the low and high homozygosity of the pistillate line respectively. Just like the pistillate character, the genetic mechanism of other important traits such as yield traits, plant type related traits, quality traits, disease resistance, photoperiod sensibility and adaptability to the environment remained unknown, which were proved to be complex quantitative traits and are limiting the improvement of the breeding level to result in the low variety yield and disease susceptibility.

First of all, the research investment is not enough in the world. As a ancient crop, the published articles on castor genetics and physiology are much little as comparison with those on castor oil processing and its medical applications as well as the main crops. Castor has ten chromosomes and the genome size is about $350 \mathrm{Mb}$ and its genome sequencing depth remained only 4.6 folds [13]. So far, only one genetic map of castor was constructed by genomeSSR markers containing 331 markers, distributed on 10 linkage groups, encompassing $1164.73 \mathrm{cM}$ of genome, with an average marker interval of 3.63cM [14]. Secondly, Low genetic diversity was found at molecular level in the core germplasm derived from over 3,000 accessions collected from across countries, which were examined with Chinese cultivation varieties and wild types in south China, which request to extend the genetic basis of parents in breeding. Thirdly, modern breeding methods especially biotechnology were rarely used in castor breeding. Actually, we improved the seed oil content by $7-11 \%$ with RNA interference to divert the common substrate from protein to the fatty acid direction. Fourthly, as one of the most adaptable crop, different ecological conditions require different varieties and cultivation methods to get good planting benefits. Take China for example, the varieties bred in north expressed senescence and poor resistance in south, but wild materials in south China lack effective improvement [15]. Therefore, the following tasks are urgent to break through the bottleneck of the castor oil industry:

1. Reveal the genetic basis and physiological and biochemical mechanism of castor beans with the methods of genomics, transcriptomics, proteomics, metabolomics and phenomics as soon as possible to make great progress, providing guidance for the breeding and cultivation of castor. It is especially true to expound the genetic law of the target traits. 
2. Study the castor germplasm all over the world integratly to mine the favorable genes and provide available genes for breeding. Innovate germplasm with gene pyramiding, distant hybridization, mutation, chromosome engineering, transgenosis, etc., to create abundant germplasm resources.

3. Carry out molecular design breeding based on enough genetic research results to realize great leap forward progress of castor breeding.

4. Conduct shuttle breeding all over the world on several representitive regions to breed varieties suitable for various ecological conditions and explore the best cultivation methods according to different places.

\section{Acknowledgement}

This paper is supported by the following funds: National natural science foundation of China (31271759); Guangdong provincial science and technology project (2013B060400024, 2014A020208116)(China); Project of enhancing school with innovation of Guangdong ocean university (GDOU2013050206) (China).

\section{References}

1. Weiss EA (1983) Oilseed crops. Longman, London, pp. 267-268.

2. Severino LS, Auld DL, Baldanzi M, Cândido MJD, Chen G, et al. (2012) A review on the challenges for increased production of castor. Agron J 104(4): 931-938.

3. Alaa MA, Yusoh K, Hasany SF (2015) Synthesis and characterization of polyurethane-rganoclay nano composites based on renewable castor oil polyols. Polym Bull 72(1): 1-17.

4. Bauddh K, Singh RP (2012) Growth, tolerance efficiency and phyto remediation potential of Ricinus communis (L) and Brassica juncea (L) in salinity and drought affected cadmium contaminated soil. Ecotoxicol Environ Saf 85(11): 13-22.
5. Campos CID, Lahr FAR, Christoforo AL, Nascimento MFD (2014) Castor oil based polyurethane resin used in the production of medium density fiberboard. Int J Compos Mater 4(4): 185-189.

6. Halek F, Delavari A, Kavousirahim A (2013) Production of biodiesel as a renewable energy source from castor oil. Clean Technol Envir 15(6): 1063-1068.

7. Madankar CS, Pradhan S, Naik SN (2013) parametric study of reactive extraction of castor seed (Ricinus communis L) for methyl ester production and its potential use as bio lubricant. Ind Crop Prod 43(1): 283-290.

8. Silva JACD, Habert AC, Freire DMG (2013) A potential biodegradable lubricant from castor biodiesel esters. Lubr Sci 25(1): 53-61.

9. Rui X (2014) Polyurethane foams containing renewable castor oil replacement: University of Missouri-Columbia, pp. 1-96.

10. Yang YF, Hu GS, Chen YJ (2013) The study of oxidative stability of castor oil based biodiesel. Adv Mater Res 724/725: 334-337.

11. Damodaran T, Hegde DM (2010) Oilseed situation, a statistical compendium.

12. Anjani K (2012) Castor genetic resources: A primary gene pool for exploitation. Ind Crop Prod 35(1): 1-14.

13. Chan AP, Crabtree J, Zhao Q Lorenzi H, Orvis J, et al. (2010) Draft genome sequence of the oilseed species Ricinus communis. Nat Biotechnol 28(9): 951-956.

14. Liu S, Yin X, Lu J, Liu C, Bi C, et al. (2016) The first genetic linkage map of Ricinus communis $\mathrm{L}$ based on genome-SSR markers. Industrial Crops and Products 89: 103-108.

15. Senthilvel S, Shaik M, Anjani K, Shaw RK, Kumari P, et al. (2017) Genetic variability and population structure in a collection of inbred lines derived from a core germplasm of castor. Journal of Plant Biochemistry and Biotechnology 26(1): 27-34.

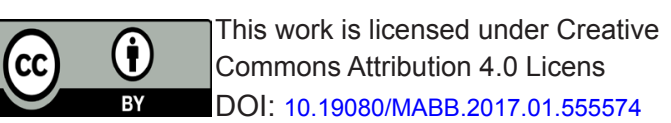

\section{Your next submission with Juniper Publishers will reach you the below assets}

- Quality Editorial service

- Swift Peer Review

- Reprints availability

- E-prints Service

- Manuscript Podcast for convenient understanding

- Global attainment for your research

- Manuscript accessibility in different formats

( Pdf, E-pub, Full Text, Audio)

- Unceasing customer service

Track the below URL for one-step submission https://juniperpublishers.com/online-submission.php 